\title{
Critical Study on Delusional Ressentiment: The Case of Filipino Community
}

\author{
Patrick Neil M. Santiago
}

Faculty Member, College of Industrial Technology-Nueva Ecija University of Science and Technology

Received: 08 Nov 2020; Received in revised form: 03 Dec 2020; Accepted: 09 Dec 2020; Available online: 13 Dec 2020

(C)2020 The Author(s). Published by Infogain Publication. This is an open access article under the CC BY license

(https://creativecommons.org/licenses/by/4.0/).

\begin{abstract}
Absurd living exists in the irrational and delusional beliefs of man. Life is worth and meaningful to anyone who attaches obligation through chastity and virtue rather than wickedness and ambition. Every individual can be a victim of sentiments. This paper investigates the basis of moral thoughts, origin of morals, impact to people, and how individuals transform themselves to affirm the present condition that shows absurdity. Finally, the present moral intervention in such community is found severe and irrational. Hence, the investigation falls on the conclusion that the present moral thought confined individuals from delusional ressentiment to become victims of sentiments. Morality then is the foundation of virtue and harmony of living, not a path of wickedness that will lead to chaos, drastic destruction and absurdity.
\end{abstract}

Keywords - absurdity, community, delusional, Filipino, morality, ressentiment, transformation, will.

\section{INTRODUCTION}

Community is composed of groups of individuals with multiple cultures, set of beliefs and standard of behavior. People in a community are mere extension of inherited morality adapted from the past civilizations. The ambiguous phenomenon through changing times, values and behavior reshape the present generation. With the community's collective effort to achieve progress and development, they become united in attaining common ground for success. This development is a general perspective aiming for autonomy and nothing but selfcentered will. Man is naturally vulnerable to his appetite such as food and sex (Cornford, 1967). His instinct is to sustain his pleasure for natural needs. But satisfaction never ends as man deals with his life and eventually transforms his will.

In a quiet community of people resides the simplicity of life, modest and honest citizens with humble dreams and practical ambitions. Out of this simplicity is the people's way of surviving their lives and earning bread and butter for their children and family. Selling vegetables, fish, meat and even kakanin is their simple means to make money. Some of them go out to farm during crop planting and harvest season of vegetables or palay just to earn a living. Others rear and tend domestic fowl like chicken and pig for their own good and extra earning. They work as if they never get weary. They help each other and through this heroic act, the spirit of bayanihan is felt in the community.

These people accept the fact that they are poor and keep on believing that God has a reason for all their hardships and struggles. They risk their lives; they sacrifice and work beyond their limits and not only parents know the concept of sacrifice but even the entire members of the family do the same. There is indeed shared responsibility in each family. They teach their siblings the worth of respecting elders, the importance of valuing education and the moral of fearing God and doing His will. Filipinos have a very natural affection when it comes to valuing a family. They have a rich culture inherited from their ancestors about strong family ties. As they preserve the culture they have, they are also influenced by Western culture and adapt Christian morality as well as a set of morality which teaches humility and faith. This morality guides the lives of people to maintain good standard of living in their community.

As people care about their family, they depend on someone or influential figure whom they perceive as ideal and just. A model or leader to lean on, an authorized or reliable person to confer with, a source of good information and virtue as the community faces struggles, anxiousness, confusions and terrible sufferings in physical world. There is always a person that stands as a leader in a 
community and that is no other than a priest. As people rely on the teaching of Christianity, it is the priest who is called the authorized and most reliable person to be asked.

Priests have been perceived as the leaders of faith. They have deprived themselves of some natural basic needs of man like sex and marriage in order to remain holy and sacred abstaining vices and sexual intercourses. However, denying their humanity is inseparable truth. Some have abused their position, committed adultery and fornication, failed to feed their flocks with pure words of God, and continued to confuse people of their purpose. Ordinary people experience such abominable customs that result to the rise of evil in the heart of an anguished soul.

From ignorance and past experiences, man carried out his will. Due to chaotic confusion and abuse of religious leaders' positions and advantages, people in the community are left in the dark. This situation gave a boomerang effect to those who pretend as holy and sacred. It generated ravaging fires in the hearts of the people that could rot and destroy the harmony in the community. Revenge and revolt found their way to take into place. The pursuit of a will that was concealed within and the phantom that was confined in the heart of man gave a rebelling blood to the followers, from the form of being submissive to becoming savaging lion.

In order to surpass sufferings, man aims to deliberate his will. It is his will that follows an ambition. Thus, its occurrence is not through a mere inertia but a repression. Mind is the power that controls over the future. This urges man to replace the priest in order to place himself to the throne. In order to pursue triumphs and so to succeed, man creates a poisonous sentiment, idea and illusion. This poison has intoxicated him to commit enviable actions triggered by biases and discriminations. Through the ignorance of people in the community and due to abuses and failures of priest, man has utilized such weaknesses as a device that would lead him to pursue his desires. For instance, he creates cyclical and distorted interpretation of certain religious practice and teachings and criticized the religious leaders as well. He starts to doubt about the credibility of a priest, his devotion and intention, questioned the practices, rituals and methods of particular religious' expressions. It is not actually a challenge of faith. It is all about dealing with the seven devils in their own selves. People get envied of the position of a priest. A wrath that triggers to become a master of their own; a lust that is irresistible; a pride that is bigger than themselves and is growing immensely. It is a gluttonous hunger for power, position and pleasure.
This phenomenon depicts how a man is transformed deliberately by his own actions and how eager he could be to pursue his selfish desires in the context of morality. It is how a man derived his actions that grasp the absurdmind. The scenario between priest and ordinary people is not terminal of this transitions or transformation. There is always a possibility to generate this phenomenon over and over again.

The issues above pose essential questions as follows: What is the basis of moral intervention in a community? Where it was originated and derived? What is the impact of adapted morality to public? How the ordinary people in the community transformed to be demi-god?

\section{METHODOLOGY}

This study utilized critical analysis method of understanding, analyzing and synthesizing issues about the delusional ressentiment of individual to explore and affirm its present notions, facets and effects to humanity. This method was adopted from J.L. Beyer. According to [2] "a critical analysis is subjective writing because it expresses the writer's opinion or evaluation of a text which was broken down into parts". The chief intent of this inquiry is to identify and explain the case of Filipino community that appears absurd and to provide substantial insights, inspirations and illumination to its readers.

\section{ANALYSIS AND EVALUATION}

\section{A. Nietzsche's Genealogy of Morals}

The German philosopher Friedrich Nietzsche (1844-1900) is a philologist and renowned as notorious iconoclast, placed as one of the most important thinkers of the modern world. Nietzsche's account supports the above discussion on priest caste and warrior caste. He justified this process through a confrontation between the two. The priests, who are powerless in a situation of combat, developed a deep and poisonous hatred to warrior. This is the mental faculty, a strategy that devises to defeat the warrior. The priestly mode of valuation is another mode that branches off from the aristocratic mode of valuation which develops into its opposites. For instance, the book of Exodus tells how Moses saved the slaves from the Egyptian masters. What made Moses to succeed is through the ressentiment of the slaves from the cruelty of master. This ressentiment is a phantom that is more powerful than the qualities of a strong warrior. Hence, this is the origin of what Nietzsche called the slave revolt in morality which according to him had began with Judaism as the source of Christianity (Magnus \& Higgins, 2006). 
Nietzsche has made a great clarification on the idea of his writings concerning the concept of "morality" in his book, On the Genealogy of Morals. He made a distinct effort to clearly identify that "good and evil" and "good and bad" have clear origins. Nietzsche stressed that the two senses of "good" have opposing meanings. From the point of view of aristocratic mode known as "master morality", "good" stands for everything that is strong and powerful, while the concept of "bad" stands for something weak and ressentiment of the lower classes (Nietzsche, 1996). The concepts of the two elements are believed to have been originated from the slave revolt known as "slave morality" (Nietzsche, 1996). The slave revolt schema in morality succeeded in reversing, redesignating the weak as "good" and the strong as "evil" (Nietzsche, 1996). This shows the perversion of the original definition defying its natural essence and meaning.

Noble morality can be described as the sense that fought enemies without mental reservation. They hardly take enemies seriously and forget about them instantly. In contrast, slave morality does not begin its tail in retaliating work that is expressed by taking revenge through permissive actions but is formed in the heart and mind of the soul which is very destructive and devastating. The weak deceive themselves of the thinking that the meek are blessed and will reach everlasting life. They invent the term "evil" to apply to the strong, in which precisely to the "good", according to the noble valuation. These later called their inferiors "bad" in the concept of worthless but not exactly the same as the idea of "evil."

Nietzsche espoused that it is a mistake to hold beasts of prey to be "evil" for their actions, that stem from their inherent strength rather than malicious intent. One should not blame others for his thirst for enemies, resistances and triumphs. Similarly, it is also absurd to resent a strong action for their misconduct because according to Nietzsche, there is no metaphysical subject on this issue. Only the weak need the illusion of the subject or the soul to hold their actions together. It is precisely absurd to be condemned by the hermit and they have no right to blame as accountable for being a bird of prey. Nietzsche concluded that by considering the two opposing valuations "good vs. bad" and "good vs. evil" one could end tremendous struggle for thousands of years, a struggle that has been started from the war between Rome (good vs. bad) and Judea (good vs. evil). Then, what had begun with Judea was the triumph of ressentiment (Bolaños, 2014).

\section{B. Impact of Slave Morality to Public}

The transition of morality evolves in the valuation through history (Magnus \& Higgins, 2006). Since Filipinos adopted Christianity, the morality that is being practiced is classified according to Nietzsche as slave morality. The morality that has been exercised in present condition relies in the concept of ressentiment that is growing deeply. The people in the community rely on the beliefs that wealth is a substance that leads them into evil and hinders them from reaching their salvation for the life after death.

The ordinary people in the quiet community remain in their own weaknesses instead of striving to overcome their struggles in life. Most of them rely on the beliefs being adopted from the doctrines. Many are poisoned and concealed in the morality that is being practiced like the principle of equality. The objective or the focus of the state is for the benefits or betterment of poor people. For instance, the democratic form of government or democracy in which the many and the poor are the rulers (Barnes, 1984). The religious institutions and government programs are usually designed to provide services only for the poor. The services needed by middle classes or upper classes became one-sided and are ignored. This concept is totally absurd. The dealings with the strong and the weak must be provided with equal treatment without discrimination.

Media is the most perverted instrument that generates such kind of slave morality. The country in this contemporary time advocates the slave morality which reshapes the values of the individual that spread in the entire community. Movies produced depicting criminals and hoodlums being asserted as heroes in their community. They are idolized by the masses. They capture the heart and the sympathy of the people. These conditions constituted a perception of virtues that led individual to do the same. This is the reason why in certain community bursts crimes, violence and chaos. They rob, kill enemies, and ruin others because of their ressentiment. Yet, again, this is not to judge them of their actions nor of their perspectives on their idols as well as the heroes and leaders that influence them. What is clear in the morality of the idols is opposed to the law of nature that threatens the harmony of living. The media sets a standard of values that in a way may ruin the harmony of the state.

\section{Metamorphoses}

Nietzsche provided a concept in tracing the roots in transforming the will of man. In his writings he explained the process of transformation to what he called metamorphosis (Nietzsche, 1969). This metamorphosis is defined as the transformation of a being into a new form of state which Nietzsche implies through the symbolic figure of a camel which represents the yes man becomes a lion that represents the will and eventually transforms into a child as a newborn babe (Nietzsche, 1996). 
Filipinos are traditionally generated to a kind of living that is reflected Nietzsche's idea on slave morality. In his book entitled, Thus Spoke Zarathustra the so-called metamorphosis is defined and represented as camel. Deprivation, shortage, and ignorance are the results of the transition from letting the flow of water into total control of the flow. Sufferings of the camel from his long-endured journey are the causes of the rise of the evils- envy, greed, wrath, pride, lust, gluttony, sloth. As observed in many communities, people have started to oppose their innate culture and traditions. Driven by many ambitions, many have left their country to work abroad in order to have better means of earning money and greater opportunities for survival. Others have become worst as they sell their soul for the small amount of money to sustain survival. Dignity had been dismantled over financial necessities. Some choose to marry rich foreign people to gain citizenship and live a luxurious life. They depended more on future security (Santiago, 2019). Some parents, even religious leaders teach them how to be wise and the common saying, "use your head not the heart" is practically applied.

The yes men or followers become covetous to rule. The intention is more ambitious and proud rather than maintaining the virtue of being pure and simple. Then after a long sacrifice, struggles and endurance of the camel, the lion starts to reign, then the camel turns to be a savage. This lion is a symbol of revolt. The successful man goes back to his place and starts a new life possessed with power. At this point, a slave now desires to become a master and developed covetous will to rule. Accordingly, the morality that develops through the feeling of ressentiment has started to dwindle and the good will of the self has started to decompose.

In the third metamorphosis, the lion transforms into a new born child. The child is a symbol of innocence, forgetfulness, and a new beginning (Nietzsche, 1996). A harmony achieving from a will into total control of flowing water has been observed. The people in a community are now used to live aftermath as wise and win their will. They can do whatever they want without being dictated by anyone not even a sincere consideration of their inherited traditions. They are now the masters of their own community. For instance, an employee possesses the authority that manipulates and controls the entire municipality which gives him the power and wealth; a sexy actress transforms herself as a public servant to lure the majority; and a Japayuki, who has been called an entertainer who serves her costumers through singing, dancing and offering sexual gratification has gained wealth and is now back home with a huge and mansion-type house, cars, and established business. Some gamblers, drug users and pushers, rapists, killers and other criminals masqueraded themselves as religious leaders who are pretending to be the enlightened ones through the word of God. They created organizations to lead churches and became leaders to gain power and respect that they had not obtained before. This also reflected to Nietzsche's writings that explained that this kind of transformation served as convalescent (Nietzsche, 1969). The rise of different religions brought by the ambitions of individual with a will for power resulted chaos, confusion and deprivation in their community. Religious leaders strictly prefer their members to have an affair only with the same faith in order to expand their organization and to avoid destruction or divisions. The so-called divine leaders who were slaves before have now become the master of set rules. Now they dictate and manipulate the lives of their members. These leaders have developed a deep and poisonous hatred which has been perceived as effective tool to gain power and maintain it through coated leadership.

Unending criticism despises the minds of the many believers and followers of those beasts. Their provocative words have made each of them to win, capture or deceive the members to submit in their reign. The leaders fetter their neighbor and their children and members in what they called faith or belief. This shows an obvious reason why this dictatorship or will for power exists - to control people. This is reflected in the writings of Nietzsche on the genealogy of morals saying about bad conscience.

According to Nietzsche, in order not to sink down from the bitter past, man relies on the state of forgetfulness. This forgetfulness is an active faculty of repression, not a mere inertia or absentmindedness. It is simply a defense mechanism. The memory is necessary for exercising control over the future that man needs to develop. Hence, it is an active faculty to work in opposition in order to fulfill the promise. The control over the future in this regard allows a morality of custom to get off the ground. The product of this morality, the autonomous individual, comes to see that man may inflict harm to those who break their promises to him. Punishment is the compensation for the accountability. Such punishment is meted out without a regard to moral considerations about the free will of the guilty person, and his accountability for his actions is simply an expression of anger. The creditor is compensated for the injury done by the pleasure he derives from the infliction of cruelty of the debtor. Hence, the concept of guilt for Nietzsche is etymologically derived from debt (Nietzsche, 1996).

Morality is reshaping people through this generation and actions of others. The concept of morality transforms or 
shifts into new definitions. The construction of things falls into its deconstruction. The endures of a camel will push to be a lion in order to be a child as an impulse to the will. This transformation or transition does not end here like what Nietzsche said but continuously circulates like a history that repeats itself.

\section{SUMMARY AND CONCLUSION}

This paper examined the issues of people's sentiments in a community, Nietzsche's genealogy of morals, impact of slave morality to public and metamorphoses were also tackled and expounded.

In the first discussion, it appears that the sentiment of ordinary people in their community creates a deep resent which carried out a specific will. Consequently, the misbehavior of the few priests and their abominable acts urged people to replace powerful priest and transfigure themselves as a demi-gods.

The idea of morality is indeed an allegorical picture of the present condition. It could suggest a confusing idea which leads someone to eschew beyond facts and think over the usual. The critical evaluation on the topic on morality is not only centered on people as a whole but also tackles the allegorical image between aristocratic morality and slave morality. The illustration in the case of morality is only a special instance that reflected the problem of society in general. Through this discussion, we could see the root of man's action and the emotion that causes resentment as a result of incapability to achieve absolute reason. What is clear is that we should take note that the idea is different from the subject. This simply means that the mistake of a person is not a mistake of a system. The failures of a person must not be blamed where he belongs. If that so, we may be driven in a wrong way. If we confine in evilness, truth is hard to achieve. The absurdity cannot be eliminated, but it can be managed. This simply means that we have to be careful of what we do to others. This idea is a mode of prevention from absurdity that might confine every individual to pitiful and shameless truth on human desires and a warning from the shadow of living deceiver.

The impact of slave morality becomes drastic in the sense that it is perverted. The virtues shift into a new definition that derived from idol of the masses. The media swift spread the adopted moral thoughts that reshaped the holistic values of masses.

Metamorphoses are absurd phenomena in our community. The instinct of man continuously ruins the essence of his existence. It could be seen how such covetous followers follow and oppose the system. Today, the way of living has shifted into new trend. All of these existed before but not as worse as they are being experienced today. Man lives in a cruel world with a savage mind and harsh reality. Nevertheless, as Nietzsche suggested, man should learn to live wisely with a profound distinction and discernment of his choices and wants. It is through his purposive and just actions where he can choose not to remain absurd.

Indeed, everyone is a victim of certain levels of sentiments and is defeated by the devils brought by resent. The ressentiment is an "imaginary revenge" that becomes bad conscience. It derived from the deepest emotion and mental reservation that hinder the preservation of truth, virtue and most of all love. Everyone is poisoned by the delusion of ressentiment caused by the covetous and greedy beast of the society who hold power and position. For the hermit, they have no right to be blamed as accountable for being a bird of prey. Everyone conceals in an irrational belief which is absolutely an absurdity. Nevertheless, morality is the foundation of virtue and harmony of living, not a path of wicked will that would lead to chaos and drastic destruction.

\section{ACKNOWLEDGEMENTS}

In his utmost gratitude the author wishes to acknowledge with profound gratitude his wife Nenita and his daughters: Sophia and Athena as well as his father Orestes and his brother Ronald who always serve as his inspiration in life's undertaking and who is always taking care of him especially in his dark and challenging times.

The author also commemorates his beloved auntie Pacencia S. Mimis who now rest in the hands of God Almighty. She will be always cherished, treasured and loved.

\section{REFERENCES}

[1]. Cornford, Francis MacDonald. trans. with intro. and notes, The Republic of Plato, New York: Oxford University Press, 1967.

[2]. Critical

Analysis. https://www2.southeastern.edu/Academics/Faculty/elejeune/c ritique.htm.

[3]. Magnus, Brent and Kathleen M. Higgins. Introduction to the Cambridge Companion to Nietzsche, UK: Cambridge University Press, 2006.

[4]. Nietzsche, Friedrich. On the Genealogy of Morals: A Polemic, trans. with an intro. and notes, Douglas Smith, New York: Oxford University Press, 1996.

[5]. Bolaños, Paolo A., On Affirmation and Becoming: A Deleuzian Introduction to Nietzsche's Ethics and Ontology, UK: Cambridge Scholars Publishing, 2014. 
International Journal of English Literature and Social Sciences, 5(6)

Nov-Dec 2020 / Available online: https://ijels.com/

[6]. Barnes, Jonathan. ed., The Complete Works of Aristotle: Politics, Princeton, NJ: Princeton University Press, 1984.

[7]. Nietzsche, Friedrich. Thus Spoke Zarathustra, trans. with an intro., R. J. Hollingdale, England: Penguin Books Ltd., 1961, 1969.

[8]. Santiago, Patrick Neil M. "On the Basis of Love: A Critical Analysis". American Journal of Humanities and Social Sciences Research (AJHSSR) e-ISSN: 2378-703X Volume-3, Issue-7, pp-34-40, 2019. 